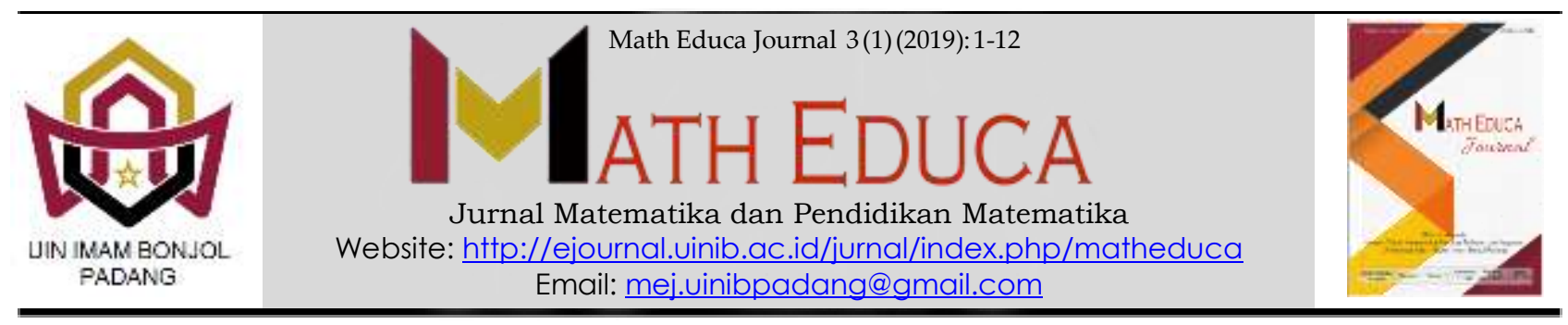

\title{
PRAKTIKALITAS PERANGKAT PEMBELAJARAN TRANSFORMASI GEOMETRI BERBASIS FLIPPED CLASSROOM PADA PESERTA DIDIK KELAS XI SMAN 1 PADANG
}

\author{
'Elsa Desmaniati, ${ }^{2}$ Rozi Fitriza \\ 1,2Tadris Matematika, Fakultas Tarbiyah dan Keguruan, UIN Imam Bonjol Padang, Indonesia \\ Email: 'elsadesmaniati17@gmail.com, 2rozifitriza@vinib.ac.id
}

Received: January 2019; Accepted: March 2019; Published: April 2019

\begin{abstract}
Abstrak
Tulisan ini membahas tentang praktikalitas produk yang merupakan hasil penelitian pengembangan perangkat pembelajaran berbasis flipped classroom untuk meningkatkan kemampuan pemecahan masalah matematis peserta didik kelas XI SMA pada materi transformasi. Penelitian pengembangan ini mengadaptasi model pengembangan Tjeerd Plomp, yang terdiri dari 3 fase yaitu: fase investigasi awal (preliminary research), fase pengembangan atau pembuatan prototipe (development or prototyping phase) dan fase penilaian (assessment phase). Data tentang praktikalitas produk diperoleh pada fase penilaian, melalui lembar observasi, wawancara dengan pendidik dan angket peserta didik. Hasil fase penilaian ini menunjukkan bahwa perangkat pembelajaran (RPP, video pembelajaran dan LKS) praktis digunakan dalam pembelajaran transformasi geometri berbasis flipped classroom.
\end{abstract}

Kata kunci: praktikalitas, perangkat pembelajaran transformasi geometri, flipped classroom

\begin{abstract}
This paper discuss about practicality of product that are result of developmental research of learning device based on flipped classroom to improve mathematical problem solving ability for XI grade students of Senior High School on transformation material. This developmental research using Tjeerd Plomp model development procedure consisting of 3 stages, namely preliminary analysis stage, prototype development stage, and assessment phase. Data of practicality are collected by observation sheets, interview and students quosionare. The result show that learning device (lesson plan, learning video, student work sheet) are practically on learning geometry transformation based on flipped classroom.
\end{abstract}

Keyword: practicality, learning device of geometry transformation, flipped classroom

\footnotetext{
${ }^{*}$ Corresponding author.

Peer review under responsibility UIN Imam Bonjol Padang.

(C) 2019 UIN Imam Bonjol Padang. All rights reserved. 


\section{PENDAHULUAN}

Seiring perkembangan zaman, teknologi informasi dan komunikasi pun mulai berkembang, hal tersebut juga berdampak pada bidang pendidikan. Salah satu contohnya yaitu dalam penggunaan media pembelajaran. Pada dasarnya pendidikan merupakan suatu proses komunikasi dari pendidik kepada peserta didik yang berisi informasi-informasi pendidikan, yang memiliki unsur-unsur pendidik sebagai sumber informasi, media sebagai sarana penyajian ide, gagasan dan materi pendidikan serta peserta didik itu sendiri (Oetomo dan Priyogutomo, 2004).

Kizito (2016) dalam penelitiannya menyatakan tentang beberapa hal yang menyebabkan suksesnya adaptasi teknologi berbasis pedagogis dalam konteks pendidikan tinggi Afrika. Pertama, kemungkinan untuk keberhasilan adaptasi akan berkurang jika tidak ada strategi yang jelas untuk adaptasi, dengan ketentuan adanya infrastruktur yang mendukung dan rencana perawatan yang didukung oleh lembaga. Kedua, peran utama seorang fasilitator tidak bisa terlalu ditekankan. Ketiga, kontribusi yang paling penting untuk mengadopsi teknologi pedagogis yaitu dengan eksplorasi tentang bagaimana menghubungkannya sebagai sebuah teori dapat digunakan untuk mengubah desain kegiatan pembelajaran.
Teori pendidikan pada saat sekarang ini telah dikembangkan untuk membantu meningkatkan model pembelajaran. Perubahan pendidikan mulai berkembang perlahan, bahkan menawarkan model pendidikan baru dan cara-cara yang unik untuk terhubung dengan peserta didik, menginformasikan, berkolaborasi, dan menilai proses pembelajaran. Dalam proses pembelajaran pendidik diharapkan untuk menerapkan model pembelajaran yang menuntun peserta didik untuk memahami dengan baik materi pembelajaran dan menyelesaikan permasalahan-permasalahan yang diberikan. Selain itu pendidik juga dituntut untuk menerapkan model yang bisa menumbuhkan minat dan keaktifan peserta didik, serta model pembelajaran yang juga mengikuti perkembangan zaman.

Model Pembelajaran berbasis Flipped classroom adalah salah satu model pembelajaran yang berpusat pada peserta didik untuk meningkatkan efektifitas pembelajaran. Flipped classroom memanfaatkan teknologi yang mendukung materi pembelajaran yang dapat diakses kapanpun dan dimanapun. Sedangkan waktu pembelajaran di kelas digunakan peserta didik untuk berkolaborasi dengan rekan-rekan mengerjakan proyek, keterampilan praktik, dan menerima umpan balik tentang kemajuan mereka. 
Graham Brent mengungkapkan bahwa flipped classroom merupakan strategi yang dapat diberikan oleh pendidik dengan cara meminimalkan jumlah instruksi langsung dalam pembelajaran sambil memaksimalkan interaksi satu sama lain (Damayanti, Herry Novis dan Sutama, 2016). Strategi ini memanfaatkan teknologi yang mendukung materi pembelajaran bagi peserta didik yang dapat diakses secara online. Hal ini membebaskan waktu di kelas yang sebelumnya digunakan untuk pembelajaran. Tucker dan Amy Roehl (2013) mengatakan bahwa peserta didik memanfaatkan waktu di kelas untuk bekerja menyelesaikan masalah, pengembangan konsep, dan terlibat dalam pembelajaran kolaboratif.

Dalam suatu proses belajar mengajar, dua unsur yang sangat penting adalah metode mengajar dan media pembelajaran. Kedua aspek ini saling berkaitan.Peran pendidik adalah menyediakan, menunjukkan, membimbing dan memotivasi peserta didik agar mereka dapat berinteraksi dengan berbagai sumber belajar yang ada, termasuk media pembelajaran. Bahkan pada saat sekarang ini media telah menjadi bagian dari kehidupan kita. Media telah mempengaruhi hampir sepanjang waktu hidup seseorang. Bahkan seorang insinyur ternama Amerika Serikat, B. Fuller mengatakan bahwa media telah menjadi "orang tua ketiga" bagi anak (pendidik adalah orang tua kedua). Meskipun perkembangannya di Indonesia belum mencapai taraf seperti itu, namun kecenderungan kearah itu sudah mulai tampak.

Dalam dunia pendidikan dan pembelajaran, peranan media juga tidak bisa diabaikan.Sebagai salah satu komponen pembelajaran, media tidak bisa luput dari pembahasan sistem pembelajaran secara menyeluruh. Pemanfaatan media seharusnya merupakan bagian yang harus mendapat perhatian pendidik dalam setiap kegiatan pembelajaran. Namun kenyataanya bagian inilah yang masih sering terabaikan dengan berbagai alasan. Alasan yang sering muncul antara lain: terbatasnya waktu untuk membuat persiapan mengajar, sulit mencari media yang tepat, tidak tersedianya biaya, dan lain sebagainya.

Pembelajaran yang dipandang sesuai serta dapat menfasilitasi pengembangan tersebut adalah pembelajaran berbasis flipped classroom. Flipped classroom merupakan strategi yang dapat diberikan oleh pendidik dengan cara meminimalkan jumlah instruksi langsung dalam praktek mengajar mereka sambil memaksimalkan interaksi satu sama lain. Strategi ini memanfaatkan teknologi yang menyediakan tambahan yang mendukung materi pembelajaran bagi peserta didik yang dapat diakses secara offline maupun online. Hal ini membebaskan waktu kelas yang sebelumnya telah digunakan untuk 
pembelajaran. Dengan strategi flipped classroom peserta didik mendapat pembelajaran tidak hanya didalam kelas saja namun diluar kelas peserta didik juga dapat mengakses atau melihat materi yang diberikan oleh pendidik secara berulang-ulang dengan bantuan video pembelajaran yang diberikan oleh pendidik. Pemilihan pembelajaran berbasis filpped classroom ini juga mengingat bahwa pada zaman sekarang ini peserta didik lebih banyak bermain gadget, maka alangkah baik jika gadget juga digunakan untuk mempermudah proses pembelajaran.

Pembelajaran dengan flipped classroom awalnya peserta didik mempelajari topik sendiri menggunakan video pembelajaran yang dibuat oleh instruktur atau bersama oleh pendidik lain. Di dalam kelas, peserta didik kemudian mencoba untuk menerapkan pengetahuan dengan memecahkan masalah dan melakukan kerja praktek salah satunya dengan pembelajaran berkelompok. Peran pendidik di kelas ini bukan untuk memberikan pelajaran awal, sehingga pendidik dapat menghabiskan lebih banyak waktu berinteraksi dengan peserta didik. Hal ini memungkinkan waktu di dalam kelas yang akan digunakan untuk kegiatan pembelajaran berbasis tambahan, termasuk penggunaan instruksi dibedakan dan pembelajaran berbasis proyek.Pembelajaran di dalam kelas dapat dimanfaatkan oleh pendidik untuk mengarahkan peserta didik melaksanakan tugas atau proyek. Tentunya hal ini dapat memicu kreatifitas peserta didik dan membuat peserta didik saling berinteraksi dalam membahas materi pembelajaran di kelas.

Peran utama dalam pembelajaran berbasis flipped classroom ini adalah video pembelajaran. Pemilihan video pembelajaran disebabkan karena peserta didik cenderung malas membaca buku paket maupun LKS, bahkan peserta didik pada umumnya tertarik dengan hal-hal yang baru serta bisa digunakan dalam situasi yang mereka inginkan. Solusi ini juga akan memberikan peserta didik banyak waktu untuk bereksplorasi dalam memecahkan berbagai macam bentuk soal dikarenakan waktu yang mereka miliki lebih banyak dalam menguasai materi.

Informasi dari pendidik di kelas XI SMA 1 Padang didapatkan bahwa, pada umumnya untuk setiap kelas nilai peserta didik belum mencapai Kriteria Ketuntasan Minimal (KKM) yang ditetapkan yaitu 80 . Hal ini menunjukkan bahwa pembelajaran matematika harus lebih ditingkatkan lagi. Pendidik telah mencoba menggunakan model pembelajaran agar peserta didik lebih aktif ketika belajar di dalam kelas, namun karena cakupan materi yang banyak pembelajaran menjadi kurang efektif. Sehingga proses pembelajaran akan membutuhkan waktu yang lama.

Berdasarkan penelitian yang dilakukan Ridha (2016), hasil penelitian menunjukkan bahwa penerapan strategi flipped mastery 
classroom memberikan pengaruh positif terhadap perolehan hasil belajar kognitif peserta didik. Sedangkan berdasarkan penelitian yang dilakukan Shafique (2015), sebagai seorang pendidik kita dapat meningkatkan filosofi mengajar melalui pembelajaran flipped classroom ini. Selain itu flipped classroom juga akan menciptakan pengalaman belajar yang baik bagi peserta didik. Pengalaman tersebut tercipta di luar maupun dalam kelas, seperti pengerjaan tugas proyek. Pembelajaran berbasis flipped classroom dipadukan dengan LKS yang menyediakan beragam soal yang mampu meningkatkan kemampuan matematika peserta didik, khususnya kemampuan pemecahan masalah matematis peserta didik.

Selain itu, terdapat beberapa alasan mengapa pendidik harus menerapkan flipped classroom, yaitu sebagai berikut (Bergman dkk,2012):

a. Flipping berbicara tentang kondisi peserta didik saat ini. Saat ini, peserta didik tumbuh dengan internet, youtube, facebook, my space, dan kemajuan digital lainnya.

b. Flipping membantu peserta didik-peserta didik yang sibuk. Peserta didik pada saat sekarang ini banyak yang sibuk dengan kegiatannya di luar, dan terlalu banyak program. Peserta didik sangat menghargai fleksibilitas dari flipping, karena inti dari materi disampaikan melalui video online, peserta didik dapat memilih untuk bekerja lebih cepat.

c. Flipping membantu peserta didik-peserta didik yang gigih belajar. Semua instruksi dapat langsung dicatat, peserta didik dengan kebutuhan khusus pun dapat menonton video sebanyak yang mereka butuhkan untuk mempelajari materi. Tidak ada lagi kepanikan untuk mencoba menyalin catatan dengan harapan bahwa mereka akan mengerti nanti. Sebaliknya, peserta didik dapat menghentikan sebentar pendidik mereka, memundurkan, dan dapat memastikan sampai benar-benar belajar konsep yang penting.

d. Flipping memungkinkan peserta didik untuk berhenti sejenak, dan melanjutkan kembali pelajaran mereka

e. Flipping meningkatkan interaksi antara peserta didik dan pendidik. Pendidik memainkan peran penting dalam kehidupan peserta didik mereka. Mereka sebagai mentor, teman, tetangga, dan ahli. Memiliki interaksi face to face dengan pendidik adalah sebuah pengalaman yang sangat berharga bagi peserta didik.

f. Flipping memungkinkan pendidik untuk memahami peserta didiknya lebih baik daripada sebelumnya

g. Flipping meningkatkan interaksi antar peserta didik. Salah satu manfaat terbesar dari flipping adalah bahwa interaksi keseluruhan meningkat: pendidik dengan 
peserta didik, dan peserta didik dengan peserta didik. Karena peran pendidik telah berubah, pendidik dapat menghabiskan waktu berbicara dengan anak-anak. Pendidik dapat menjawab pertanyaan peserta didik, bekerja dengan kelompokkelompok kecil, dan membimbing belajar dari setiap peserta didik secara individual.

h. Flipping bisa diterapkan untuk keadaan yang berbeda. Flipping menunjukkan kepada kita betapa banyak peserta didik yang membutuhkan pendidik dan betapa kuat flipping dalam mencapai berbagai kemampuan peserta didik.

i. Flipping menggganti manajemen di dalam kelas. Peserta didik yang biasanya ribut dikelas tidak akan menjadi pusat perhatian lagi karena semua peserta didik sibuk dengan proyek yang dilakukannya.

j. Flipping merubah cara bicara/ komunikasi kepada orang tua. Pembelajaran ini akan menjawab pertanyaan orang tua mengenai bagaimana anaknya dalam belajar. Karena peserta didik telah dibekali pengetahuan terlebih dahulu maka mereka ada bekal dalam pembelajaran di kelas sehingga keributan di kelas menjadi berkurang.

k. Flipping dapat mendidik orang tua

I. Flipping membuat kelas lebih transparan. Orang tua dapat mengetahui materi yang dipelajari anaknya hanya dengan beberapa klik. m. Flipping merupakan salah satu cara pendidik mensiasati ketidak hadirannya

n. Flipping membantu dalam menguasai materi.

Berdasarkan paparan di atas maka penulis menilai penting untuk dikembangkan perangkat pembelajaran matematika berbasis flipped classroom yang valid, praktis dan efektif. Dalam tulisan ini diuraikan tentang praktikalitas perangkat pembelajaran yang dihasilkan.

\section{METODE PENELITIAN}

Jenis penelitian yang dilakukan adalah penelitian dan pengembangan (Research and Development). Penelitian pengembangan ini mengadaptasi model pengembangan yang digagas oleh Tjeerd Plomp. Model ini terdiri dari 3 tahap yaitu: fase investigasi awal (preliminary research), fase pengembangan atau pembuatan prototipe (development or prototyping phase) dan fase penilaian (assessment phase) (Plomp, T dan N. Nieveen, 2013)

Agar diperoleh perangkat pembelajaran berbasis flipped classroom yang valid dilakukan investigasi awal (preliminary research). Fase investigasi awal (preliminary research) terdiri dari analisis kebutuhan, analisis kurikulum, analisis peserta didik dan analisis konsep. Berdasarkan hasil analisis pada fase preliminary research, dirancang perangkat pembelajaran berbasis flipped classroom. Pada 
fase pengembangan atau pembuatan prototype (development or prototyping phase) dirancang perangkat pembelajaran berbasis flipped classroom. Pada prototyping stage, pembuatan prototipe ini dilakukan evaluasi formatif. Fase pengembangan atau pembuatan prototipe (prototyping stage) terdiri atas prototipe 1, yaitu evaluasi diri sendiri (self evaluation); prototipe 2, yaitu expert review dan evaluasi satu-satu; prototipe 3, yaitu evaluasi kelompok kecil, dan prototipe 4 yang merupakan hasil dari evaluasi formatif. Perangkat pembelajaran berbasis flipped classroom yang telah dirancang dievaluasi sendiri (self evaluation) dan divalidasi oleh para ahli (expert review). Validasi perangkat dilakukan oleh tiga orang dosen Matematika, satu orang dosen Teknologi Pendidikan dan satu orang dosen Bahasa Indonesia. Setelah dihasilkan perangkat pembelajaran berbasis flipped classroom yang valid, dilakukan evaluasi orang per orang (one-to-one), evaluasi kelompok kecil (small group) dan uji coba lapangan (field test) untuk melihat kepraktisan. Pada fase penilaian (assessment stage), dilakukan uji lapangan pada kelas XI IPA SMA Negeri 1 Padang untuk melihat praktikalitas dan efektivitas. Data praktikalitas produk dikumpulkan melalui lembar observasi keterlaksanaan RPP, lembar wawancara dan angket respon peserta didik. Kategori kepraktisan dapat dilihat pada Tabel 1.
Tabel 1. Kategori Kepraktisan

\begin{tabular}{ccc}
\hline No & Nilai & Kriteria \\
\hline 1 & $80 \%<x \leq 100 \%$ & Sangat praktis \\
2 & $60 \%<x \leq 80 \%$ & Praktis \\
3 & $40 \%<x \leq 60 \%$ & Cukup praktis \\
4 & $20 \%<x \leq 40 \%$ & Kurang praktis \\
5 & $0 \%<x \leq 20 \%$ & Tidak praktis \\
\hline
\end{tabular}

\section{HASIL PENELITIAN DAN PEMBAHASAN}

\section{Hasil Penelitian}

1. Hasil Lembar Observasi Keterlaksanaan RPP

Dalam melihat praktikalitas perangkat pembelajaran matematika berbasis flipped classroom, ditinjau keterlaksanaan RPP selama pembelajaran menggunakan lembar observasi. Analisis hasil observasi keterlaksanaan RPP berbasis flipped classroom dapat dilihat pada tabel 2 berikut.

Tabel 2. Hasil Observasi Keterlaksanaan RPP

\begin{tabular}{ccc}
\hline $\begin{array}{c}\text { Pertemuan } \\
\text { Ke- }\end{array}$ & $\begin{array}{c}\text { Nilai } \\
\text { Keterlaksaan } \\
\text { RPP }\end{array}$ & Kriteria \\
\hline I & 0,855 & Sangat Praktis \\
II & 0,855 & Sangat Praktis \\
III & 0,895 & Sangat Praktis \\
IV & 0,921 & Sangat Praktis \\
V & 0,921 & Sangat Praktis \\
\hline
\end{tabular}

Berdasarkan tabel di atas, nilai keterlaksanaan RPP flipped classroom dalam 5 kali pertemuan mendapatkan kriteria sangat praktis. Hal ini menunjukkan bahwa RPP yang dikembangkan sudah sesuai dengan prinsip pelaksanaan pembelajaran. Nilai keterlaksanaan RPP paling rendah didapatkan pada pertemuan I dan II. Hal ini disebabkan 
karena peserta didik belum terbiasa melakukan kegiatan pembelajaran menggunakan perangkat pembelajaran berbasis flipped classroom.

Pada tahap ini dilakukan pembelajaran di kelas berdasarkan RPP yang telah dikembangkan, yaitu dengan menggunakan video dan LKS berbasis flipped classroom. Peserta didik tersebut memberikan pendapat, saran dan kritikan terhadap video dan LKS yang dikembangkan.

\section{a) Pertemuan Pertama}

Pada pertemuan pertama, dilakukan evaluasi kelompok kecil berdasarkan langkah-langkah RPP pertemuan 1. Sebelum kegiatan berlangsung, peserta didik diwajibkan menonton video pembelajaran yang telah diberikan sebelumnya. Pada pelaksanaan pembelajaran, peserta didik mengerjakan kegiatan pada LKS secara berkelompok yang masing-masing terdiri dari dua orang peserta didik sehingga terdapat tiga kelompok belajar dalam kelas. Pada pertemuan pertama ini, peserta didik agak kesulitan dalam menjawab soal-soal pemecahan masalah. Peserta didik belum terbiasa dalam menjawab soal pemecahan masalah sesuai langkah-langkah yang tepat. Oleh karena itu, guru membimbing peserta didik untuk menjawab soal-soal pemecahan masalah tersebut dan menggiring langkah-langkahnya. Peserta didik dapat mengerjakan LKS sampai mengerjakan soal latihan. Kendala yang dialami pada pertemuan pertama adalah peserta didik belum terbiasa dengan pembelajaran flipped classroom sehingga membutuhkan waktu yang relatif lama dalam mempersiapkan pembelajaran.

Setelah selesai melaksanakan pembelajaran pada pertemuan pertama, peserta didik diminta mempersiapkan diri untuk mempelajari materi refleksi bagian 1 dengan menonton video pembelajaran 2.

b) Pertemuan Kedua

Pada pertemuan kedua, proses pembelajaran yang dilaksanakan berdasarkan langkah-langkah pembelajaran pada RPP pertemuan 2 . Peserta didik mulai terbiasa dengan pembelajaran flipped classroom sehingga tidak perlu persiapan yang terlalu lama. Peserta didik sudah mulai terbiasa menonton video pembelajaran. Pada pertemuan kali ini, peserta didik mengerjakan LKS 2 secara berkelompok sesuai dengan kelompok pada pertemuan sebelumnya. Soal-soal pada Latihan 2 ini pun dapat dikerjakan peserta didik. Berdasarkan pembelajaran kedua ini, tidak terdapat revisi pada perangkat pembelajaran.

Setelah selesai mengerjakan latihan dan pembelajaran ditutup, peserta didik diinstruksikan untuk menonton video 
pembelajaran 3 untuk pertemuan selanjutnya. Peserta didik diminta mempersiapkan diri untuk mempelajari materi refleksi bagian kedua.

c) Pertemuan Ketiga

Pada pertemuan ketiga, proses pembelajaran yang dilaksanakan berdasarkan langkah-langkah pembelajaran pada RPP pertemuan 3 . Peserta didik sudah terbiasa dengan pembelajaran flipped classroom sehingga tidak perlu persiapan yang terlalu lama dibandingkan dengan pertemuan sebelumnya. Sebelumnya peserta didik diwajibkan untuk menonton video pembelajaran 3. Pada pertemuan ini peserta didik mengerjakan LKS 3 secara berkelompok sesuai dengan kelompok pada pertemuan sebelumnya. Peserta didik bisa mengerjakan soal pada Latihan 3 dan sesuai dengan alokasi waktu yang tersedia.

Kendala yang ditemukan pada pertemuan ketiga ini yaitu peserta didik agak kesulitan dalam menentukan rumus masing-masing refleksi, karena bagian dari refleksi tergolong banyak. Yang dilakukan guru untuk mengatasinya adalah dengan menggiring pola pikir peserta didik untuk memahami konsepnya berdasarkan grafik. Grafik tersebut selalu disajikan di awal LKS. Dengan menggiring pola pikir peserta didik tersebut, maka peserta didik dengan lebih mudah mengingat dan memahami macammacam rumus refleksi.

Setelah selesai mengerjakan latihan dan pembelajaran ditutup,peserta didik diberi instruksi untuk menonton video pembelajaran 4 untuk pertemuan berikutnya. Peserta didik diminta mempersiapkan diri untuk mempelajari materi yang telah disajikan dalam video tersebut yaitu mengenai rotasi.

d) Pertemuan Keempat

Pembelajaran dilaksanakan sesuai denganlangkah-langkahpembelajaran pada RPP 4. Pada pertemuan keempat ini, juga tidak terdapat kendala dalam penggunaan perangkat pembelajaran. Semua kegiatan terlaksana dengan baik dan semua soal Latihan 4 juga dapat diselesaikan oleh peserta didik sesuai dengan alokasi waktuyangtersedia.

e) Pertemuan Kelima

Pembelajaran dilaksanakan sesuai dengan langkah-langkah pembelajaran pada RPP 5. Pada pertemuan kelima ini, tidak terdapat kendala dalam penggunaan perangkat pembelajaran. Semua kegiatan terlaksana dengan baik dan semua soal Latihan 5 juga dapat diselesaikan oleh peserta didik sesuai dengan alokasi waktu yang tersedia. Revisi LKS berdasarkan pembelajaran kelima adalah menambah ukuran kotak jawaban yang masih terlalu 
kecil dan memperkecil ukuran kotak jawaban yang terlalu besar.

2. Hasil Angket Praktikalitas Respon Peserta Didik

Analisis hasil angket praktikalitas perangkat pembelajaran matematika berbasis flipped classroom menurut peserta didik dapat di lihat pada Tabel 3.

Tabel 3. Hasil Angket Praktikalitas Perangkat Pembelajaran Matematika Berbasis Flipped Classroom Menurut Peserta Didik

\begin{tabular}{|c|c|c|c|}
\hline \multicolumn{2}{|c|}{$\begin{array}{l}\text { Sub Variabel } \\
\text { Praktikalitas }\end{array}$} & $\begin{array}{c}\text { Nilai } \\
\text { Praktis }\end{array}$ & Kriteria \\
\hline \multirow{3}{*}{$\begin{array}{l}\text { Video } \\
\text { Pem- } \\
\text { belaja } \\
\text { ran }\end{array}$} & $\begin{array}{l}\text { Keterbacaan } \\
\text { dan } \\
\text { kejelasan }\end{array}$ & 0,916 & $\begin{array}{l}\text { Sangat } \\
\text { Praktis }\end{array}$ \\
\hline & $\begin{array}{l}\text { Keterpakaia } \\
\text { ndan } \\
\text { kemudahan } \\
\text { penggunaan }\end{array}$ & 0,833 & $\begin{array}{l}\text { Sangat } \\
\text { Praktis }\end{array}$ \\
\hline & $\begin{array}{l}\text { Kecukupan } \\
\text { waktu }\end{array}$ & 0,863 & $\begin{array}{l}\text { Sangat } \\
\text { Praktis }\end{array}$ \\
\hline \multirow{3}{*}{ LKS } & $\begin{array}{l}\text { Keterbacaan } \\
\text { dan } \\
\text { kejelasan }\end{array}$ & 0,858 & $\begin{array}{l}\text { Sangat } \\
\text { Praktis }\end{array}$ \\
\hline & $\begin{array}{l}\text { Keterpakaia } \\
\text { ndan } \\
\text { kemudahan } \\
\text { penggunaan }\end{array}$ & 0,851 & $\begin{array}{l}\text { Sangat } \\
\text { Praktis }\end{array}$ \\
\hline & $\begin{array}{l}\text { Kecukupan } \\
\text { waktu }\end{array}$ & 0,847 & $\begin{array}{l}\text { Sangat } \\
\text { Praktis }\end{array}$ \\
\hline \multicolumn{2}{|c|}{ Rata-rata Nilai Praktis } & 0,874 & $\begin{array}{l}\text { Sangat } \\
\text { Praktis }\end{array}$ \\
\hline
\end{tabular}

Berdasarkan tabel di atas terlihat bahwa rata-rata nilai praktikalitas perangkat pembelajaran matematika berbasis flipped classroom menurut peserta didik adalah 0,874 dengan kriteria sangat praktis.

\section{Pembahasan}

Suatu produk dikatakan berkualitas jika memenuhi 3 kriteria, yaitu valid, praktis dan efektif. Hal tersebut sesuai dengan pendapat Nieveen dalam Plomp (2013), bahwa kriteria untuk mendapatkan kualitas produk yang baik yaitu valid, praktis dan efektif. Pada tulisan ini dibahas kepraktisan perangkat pembelajaran yang dikembangkan. Berdasarkan hasil penelitian diketahui bahwa perangkat pembelajaran matematika berbasis flipped classroom sudah praktis.

Suatu perangkat pembelajaran yang baik hendaklah bersifat praktis. Kriteria yang dipakai untuk menilai praktikalitas dalam pengembangan perangkat ini adalah keterlaksanaan pembelajaran menggunakan perangkat pembelajaran matematika berbasis flipped classroom. Dalam menilai kepraktisan pada perangkat ini, maka dikumpulkan data melalui observasi dan wawancara dengan pendidik dan angket praktikalitas yang diisi oleh peserta didik.

Aspek-aspek yang dilihat untuk praktikalitas perangkat pembelajaran matematika berbasis flipped classroom ini adalah aspek keterbacaan dan kejelasan, keterpakaian dan kemudahan penggunaan, serta kecukupan waktu. Berdasarkan hasil observasi, wawancara dan angket diperoleh 
kesimpulan bahwa video pembelajaran dan LKS dapat dipahami dengan baik, mudah digunakan, menarik, mampu memotivasi peserta didik untuk belajar, dan waktu yang digunakan cukup memadai. Hal ini menunjukkan bahwa video dan LKS yang dikembangkan sudah praktis karena sesuai dengan pendapat Nieveen yang menyatakan bahwa sebuah perangkat pembelajaran dikatakan praktis jika perangkat tersebut dapat digunakan dengan mudah oleh pendidik dan peserta didik dalam pembelajaran.

Walaupun terdapat beberapa kendala namun tidak mengurangi kelancaran proses pembelajaran. Pada proses pembelajaran, sebagian besar peserta didik menonton video secara offline dibandingkan online. Akan tetapi, dampak terhadap perolehan pengetahuan peserta didik yang menonton online dan offline sama saja.

Oleh karena itu, penggunaan RPP, video pembelajarandan LKS berbasis flipped classroom dapat membantu pendidik dalam kelancaran pembelajaran. Kemudian penggunaan video pembelajaran dan LKS berbasis flipped classroom dapat memudahkan peserta didik memahami materi pelajaran. Hal ini sejalan dengan hasil penelitian Kemp dan Dayton (dalam Sutrisno, 2015: 12), bahwa pemanfaatan media pembelajaran memberikan dampak positif, diantaranya: penyampaian materi tidak kaku, waktu pembelajaran dapat dipersingkat, kualitas pembelajaran dapat ditingkatkan serta pembelajaran dapat diberikan dimana dan kapan saja. Sehingga pembelajaran berbasis flipped classroom efektif dan efisien.

\section{SIMPULAN DAN SARAN}

Berdasarkan hasil analisis data yang telah dilakukan dapat disimpulkan perangkat pembelajaran berbasis Flipped Classroom yang dirancang praktis digunakan untuk meningkatkan kemampuan pemecahan masalah peserta didik kelas XI IPA. Berdasarkan simpulan di atas, maka perangkat pembelajaran berbasis Flipped Classroom dapat dijadikan sebagai pedoman bagi pendidik dalam melaksanakan pembelajaran untuk meningkatkan kemampuan matematis peserta didik.

\section{REFERENSI}

Bergman, Jon, dan Sams, Aaron. 2012. Flip Your Classroom: Reach Every Student in Every Class Every Day.WashingtonDC: International Society for Technology in Education.

Damayanti, Herry Novis dan Sutama. 2016. "Efektivitas Flipped Classroom Terhadap Sikap dan Ketrampilan Belajar Matematika di SMK". Jurnal Managemen Pendidikan, 11 (2), 2-8

Kizito, Rita Ndagire. 2016. "Connectivism in Learning Activity Design: Implications for Pedagogically-Based Technology Adoption in African Higher Education Contexts". International Review of Research in Open and Distributed Learning, 17 (2):19-39. 
Oetomo, B.S.D danPriyogutomo, Jarot. 2004. KajianTerhadap Model e-Media dalam Pembangunan Sistem e-Education, Makalah Seminar Nasional Informatika 2004 di Universitas Ahmad Dahlan Yogyakarta pada 21 Februari 2004.

Plomp, T. dan N. Nieveen. 2013. Educational Design Research. Enschede: Netherland Institute for Curriculum Development (SLO).

Ridha, Muhammad, dkk. 2016. "Pengaruh Flipped Mastery Classrom terhadap Perolehan Hasil Belajar Kognitif Mahasiswa". Jurnal Pendidikan: Teori, Penelitian, dan Pengembangan, 1 (4), 655-661
Shafique, Mohammad. 2015. "A Study on the Effectiveness of Flipped Teaching in College Math Classroom". International Journal of Education and Information Technology, 1 (2), 29-33

Sutrisno, Ashari. 2015. Desain dan Pengembangan Media Pembelajaran. Yogyakarta: Pusat Pengembangan dan Pemberdayaan Pendidik dan Tenaga Kependidikan (PPPPTK) Matematika.

Sugiyono, (2012). Metode Penelitian Kuantitatif, Kualitatif dan R\&D. Bandung: Alfabeta.

Wasidi. (2009). Peningkatan Daya Serap Materi Evaluasi Pendidikan dengan Latihan Terbimbing pada Progra Studi PLS FKIP UNIB. Jurnal Kependidikan Triadik, 12(1), 63-70. 